\title{
The CSSHE Conference, 1975: Rival Patron Saints
}

\author{
JANET SCARFE*
}

"Charles Lutwidge Dodgon: His Interest in Higher Education." It is not too difficult to imagine that title appearing one day in the Dissertation Abstracts. The years he spent at Christ Church, Oxford (1850-1881) coincided with the bitter controversies and sweeping reforms in the second half of the nineteenth century which transformed that ancient university. Parliamentary commissions scrutinized and parliament interfered with Oxford's administration, admission procedures and finances. Within the university itself, the debates over curriculum, teaching, research and social responsibility were intense. Some dons were determined to maintain the status quo; among their critics, "a propogandist spirit has been developed which desires to carry university teaching and university influence to every corner of the land." (Times, 21 August, 1873, p. 5.

Quoted in Ward, W.R. Victorian Oxford. London: Cass, 1965. p. 263).

Dodgson's particular interest in these events will be left to thesis writers in history, English or higher education. There are broad parallels between the criticisms and reevaluations of university education in Dodgson's day and our own. More than this, browsing in Through the Looking Glass suggests that his writings merit attention by not only experts in nonsense and mathematical axioms, but participants in and observers of higher education. Academic planners and administrators, for instance, perplexed by the complexity of the problems and pressures in institutions of higher education will sympathize with the distress of the Walrus and the Carpenter on surveying their beach all cluttered up with sand:

"If seven maids with seven mops swept it for half a year,

Do you suppose," the Walrus said, "That they could get it clear?"

"I doubt it," said the Carpenter, and shed a bitter tear.

To my disappointment, there were few, if any, allusions to Dodgson or his accomplice, Lewis Carroll, during the annual CSSHE conference. There were no invocations for aid, supplications or combing of his texts for clues of assistance with the mathematical complexities of formula financing. The focus of attention was the cluster of recent provincial reports investigating post-secondary education (Worth, Wright, Oliver and Graham), although the design of the programme, the experiences and concerns of the participants and the implications and repercussions of the reports themselves were sufficiently broad to turn the conference into a forum on the current state of postsecondary education in Canada.

My scant knowledge of Lewis Carroll did not grow, and I discovered that my facility with the French language was less than I imagined. However, my rather nodding

*Graduate student, Higher Education Group, University of Toronto 
acquaintanceship with the four reports certainly changed. After the discussions I was more familiar with the reports, more aware of the philosophical stances of their authors, of differing provincial approaches to post-secondary education and of the rapid change in the political and public attitudes toward universities between the first and last reports. Not least, some of my confusion over the domain of higher education had evaporated, and some frustration at the apparently disparate approaches of professional administrators and faculty members disappeared. My bewilderment at the Canadian predilection for referring matters to "commissions of inquiry" remained, but my suspicion that higher educationists put their faith in "planning" as the panacea of all ills or used it in the way that those frightened by vampires draped their doorways with garlic fronds was not confirmed -- to my relief.

By now, the flaws in my perception of things Canadian will be apparent, together with a propensity for things past. Since arriving from Australia in August, 1974, for a full-time M.A. programme with the Higher Education Group at the University of Toronto, I've been perplexed by the nature of "higher education," at times annoyed and at others excited by the uncertainty of its parameters as a "field" let alone a discipline. For a student of that dowager of disciplines, history, who has as much (if not more) in sympathy with Victorian England than contemporary North America, such simple matters as looking at current issues, writing in the present tense about controversies without a polestar such as hindsight (read "perspective") takes more re-orientation of thinking patterns than expected. There is little culture-shock for Australians living in Canada (although the differences are more intriguing than the similarities), but there are considerable jolts for the traditional type of historian who undertakes a course in higher education. Accommodating to this sort of statement, for example, takes time: "it is the specification of objectives, the specification of means towards the objectives, the specification of methods of monitoring the success of the means ..." (Jabberwocky?). Besides, my main interests in higher education are not in planning, administration, systems and accountability; my experience as a teaching fellow at the University of Sydney involved straddling the fence between the faculty meadow and the student moor, rather than the faculty's and administrators' pastures. I managed, however, to balance the various Conference sessions I attended: several of the Canadian Historical Association, but also a more informal and thinly attended symposium sponsored by the University of Alberta S.C.M., entitled "The Academic Game - the student viewpoint," altogether the most gloomy outlook on universities I encountered during the conference.

Still wondering at Lewis Carroll's contribution to the provincial reports, I would like to sponsore a rival claimant to the position of patron saint of the conference: T.S. Eliot. Some lines from "The Rock" were suggested by Professor Malcolm Taylor's brief opening remarks, as being appropriate to the current plight (plights?) of universities which emerged quickly and dominated the discussions: the university "must be forever building, for it is forever decaying within and attacked from without, for this is the law of life."

Professor Baker, opening the "challenges" to the reports, drew a parallel between the "Books" of Victorian England - on public health, factory conditions and education - which were grounded in faith in the importance of gathering and recording informa- 
tion as the key to blueprints for improvement, and these particular reports which were similarly "snapshots of inevitable changes," rather than forecasts, platforms or prospectuses for the future. He expressed concern that while all reports recommended a participatory form of government, drawing on interests inside and outside the university, the difficulties of ensuring that constituencies were duly represented remained unresolved. Professor André Côté also saw those documents as illustrating both recent history and evolutionary trends. His comments on the process of change (referring particularly to the example of the CEGEPs and the issue of accessibility) underlined the difficulties in reconciling external pressure on the universities to change their long-held assumptions and practices and the universities' own convictions about the wisdom of such change. Professor John Dennison, whose stamina in re-reading the reports in a day was impressive, concentrated on one central theme: the apparent incompatibility between excellence and equality which sprang from the reports' shared faith in egalitarianism. "Attacked from without," pressured into accepting students with qualifications that were academically dubious by society's insistence on wider participation in post-secondary education, academics were deeply perturbed by the consequences - decaying standards within the university. The obligation or responsibility to be more "open" or responsive to society's expressed needs was a double-edged sword. (Such arguments were doubtless familiar to Dodgson. It was interesting that Professor Baker had considered the garment rending over standards was due to somewhat exaggerated fears.) Professor Dennison translated the nebulous term "standards" - a curious, usually ill-defined mixture of "observation" and intuition - into terms of implications for students and, in consequence, inevitably, for the university.

During a discussion group on the following day, Professor Dennison expounded the obverse side of the coin, the dissatisfaction of students with the university's attention (or inattention) to part-time or evening students. Disappointed in the quality of teach ing at universities and frustrated by their rigid adherence to traditional curricula and timetables, some of these students had made quite a dramatic gesture of defiance, for there existed examples of high-achieving, wealthy students deliberately choosing to attend community colleges in British Columbia, in preference to either of the universities. Thus they avoided the poor instruction and inflexible structuring of timetables which they associated with universities. The decision to do this was made perhaps in a situation not like that in the Lobster Quadrille, with the adventuresome whiting enticing the cautious snail toward the challenge: to the snail's timid protests

"What matters it how far we go?" his scaly friend replied.

"The farther off from England the nearer is to France.

There is another shore, you know, upon the other side.

Then, turn not pale, beloved snail, but come and join the dance." This particular discussion group had begun by discussing another aspect of the problems created by internal weakness and external pressure, the so-called "glacial spread" of government control. To an Australian, from a country where the number of universities is small and the relationship with the federal and state governments relatively simple, the exchange of information across provinces was intriguing, especially about the various schemes to provide buffers between the universities and provincial governments. In New Brunswick, there seemed no real problem of government control; Alberta's buffer body 
had been disbanded after the Worth report and the universities were feeling some pressure; in Manitoba, the buffer body seemed a facade. In Ontario, the government relied increasingly on the new Ontario Council on University Affairs and the Council of Ontario Universities for distributing the allocated funds, and it was suggested that universities in Ontario could hardly decry any existing control as they had neither learned to govern themselves, nor taken any initiative in planning for leadership, not, in particular, articulating their unique role.

From raising the issue of the peculiar functions of universities, it was but a short step to the perplexing issue, "parity of esteem," raised by Professor Gordon Campbell's "challenge." Conversation ranged from arrogance encountered in universities about "the factory down the street," the sense of inferiority among polytechnic faculty in the United Kingdom at conferences involving their university brethren, to comments on the fine programmes and palatial buildings offered by some community colleges as a tempting bait and the preference, at least in British Columbia, of some students for the community college over the university. An acceptable definition of "parity of esteem" was elusive: "parity of esteem" defied simple description. Professor Campbell maintained that parity, its advent and acceptance must be set within a global context, as a product of philosophy. He described it as embodied in an interconnected system of higher education, comprising many choices and purposes for the student; different institutions, then, would be worthy of esteem for different reasons. Convincing the public, (whether employers, potential students, or parents) and students that "parity of esteem" existed between these different educational institutions was a long-term public relations task, hampered by the reluctance within universities themselves to accept the concept and, in particular, its practical implications. Professor Dennison remarked that inequity of esteem was decreasing in British Columbia: fewer and fewer eyebrows were raised at students who opted for community colleges when eligible for university. Perhaps there is a warning here for universities who must recognize that they are but part of a whole system of post-secondary education:

"Will you walk a little faster," said a whiting to a snail,

"There's a porpoise close behind us, and he's treading on my tail."

Charles Dodgson contributed to the flurry of pamphlets on university reform with a long satirical verse, which included these lines:

"Neglect the heart, and cultivate the brain -

Then intellect's proud flag shall be unfurled,

And Brain, and Brain alone, shall rule the world!"

A catalogue of topics neglected in the conference discussions is hardly fair, for all that could be attempted was to gauge the state of the walrus' beach from particular vantage points. Nevertheless, Dodgson's burlesque seems appropriate comment against those in the university community who would transform what, arguably, is a prime concern: students into statistics - for enrolment, for transfer, for attrition, all in the name of the preservation of academic standards.

The various positions of administrator, faculty community and student were represented at the conference, some to a great, others to a far lesser extent. The administrators and faculty were visible in the discussions, and some interpretations of the community position were brought out at the Round Table forum. Most neglected was the 
student perspective, but some indication of it appeared in the University of Alberta S.C.M. symposium, entitled, "The Academic Game - the student perspective." It was hardly a rival attraction to the CSSHE: a small group of students exchanged experiences they had had in the community over which "intellect's proud flag" flutters. They spoke in terms becoming thread-bare from overuse - about being merely a number on a library card, about pre-occupied faculty, mediocre teaching and the inequities of grading. Yet the passion of their presentation prevented a polite yawn, and the small number of participants heightened the sense of their vulnerability and anonymity in the empire of intellect. This is not to suggest that the well-being of a university is entirely determined by friendly relations between faculty, administrators and students alone, or that Newman's convictions about the pastoral role of the university teacher are appropriate or acceptable. Rather it is a lament that the idea of a university (to borrow a much abused phrase) as perceived by these groups of participants was so diverse, so unrelated. One was highly complex, concerned with the mechanics of reconciling and realising the university's traditional mandates of teaching, research and community service. The key, of course, lies in the quality of communication between the vested interests of planner, faculty and student, and it was here that the students voiced most disillusionment. It is that quality which gives meaning and conviction to T.S. Eliot's comments on the various purposes which have been found for higher education. Rather than deploring the confusion of aims and ideals, he insisted that:

we must go on inventing new ones. Each answer is a clue to what education means to somebody, an incentive for finding out what it means for oneself. If it meant exactly the same thing to everybody, the world would have been a very dead place indeed; so that we have not reason to deplore the fact, if we find the meaning of education is elusive . . .

Such sentiments give Eliot the exalted position of parton saint of the CSSHE conference. 